University of Michigan Law School

University of Michigan Law School Scholarship Repository

Law \& Economics Working Papers

7-23-2012

\title{
University of Michigan Bar Passage 2004-2006: A Failure to Replicate Professor Sander's Results, With Implications for Affirmative Action
}

Richard O. Lempert

University of Michigan Law School, rlempert@umich.edu

Follow this and additional works at: https://repository.law.umich.edu/law_econ_current

Part of the Educational Assessment, Evaluation, and Research Commons, and the Legal Education Commons

Working Paper Citation

Lempert, Richard O., "University of Michigan Bar Passage 2004-2006: A Failure to Replicate Professor Sander's Results, With Implications for Affirmative Action" (2012). Law \& Economics Working Papers. 51. https://repository.law.umich.edu/law_econ_current/51

This Article is brought to you for free and open access by University of Michigan Law School Scholarship Repository. It has been accepted for inclusion in Law \& Economics Working Papers by an authorized administrator of University of Michigan Law School Scholarship Repository. For more information, please contact mlaw.repository@umich.edu. 


\title{
University of Michigan Bar Passage 2004-2006: A Failure to Replicate Professor Sander's Results, With Implications for Affirmative Action
}

\author{
Richard O. Lempert
}

$7 / 23 / 2012$

In a recent issue of the Denver Law Review, Professor Richard Sander present data on race-based affirmative action that purportedly support his theory that any benefits African Americans enjoy from affirmative action are more than offset by detrimental effects of academic mismatch. Specifically, he references a yet unpublished study in which he claims to have found that for the years 2004-2006 the bar passage rate of African-American graduates of the University of Michigan Law School is 62 percent for first time takers rising to only 76 percent after multiple takes. This paper shows that these results are quite implausible given the best data we have on African American bar passage rates at schools similar in selectivity to Michigan, and then reports the results of an effort to replicate Professor Sander's methods with more complete data. The replication yields quite different results as it indicates that during the years Professor Sander studied the bar passage rate for Michigan Law School's African American alumni was about $78 \%$ on first attempt with a lower bound estimate exceeding $90 \%$ where there had been an opportunity for repeat test taking. Moreover, the data are quite inconsistent with the predictions of mismatch theory. Hispanic students, many of whom benefited from affirmative action, had about the same bar pass rates as white students who did not, and Asian students who did not benefit from affirmative action had bar pass rates not much different from those of African American students who did benefit. 


\title{
University of Michigan Bar Passage 2004-2006: A Failure to Replicate Professor Sander's Results - With Implications for Affirmative Action
}

\author{
Richard Lempert*
}

\section{$\underline{\text { Introduction }}$}

\begin{abstract}
In a recent issue of the Denver Law Review ${ }^{1}$, Richard Sander takes advantage of an opportunity to respond to critics of an article he wrote on social class in American law schools to present data on race-based affirmative action that purportedly support his theory that any benefits African Americans enjoy from affirmative are more than offset by detrimental effects of academic mismatch. ${ }^{2}$ Specifically, he references a yet unpublished study he did which according to him show that for the years 2004-2006 the bar passage rate of African-American graduates of the University of Michigan Law School taking a bar examination for the first time was 62 percent and when one allows for multiple takes 76 percent. Not only are these results quite implausible given the best data we have on the rate at which African American's pass the bar at schools similar in selectivity to Michigan, but when I attempted to replicate Professor Sander's study with a data base that cut missing cases in half and authoritatively resolved ambiguous racial classifications, I found that first time bar passage rates for Michigan's African
\end{abstract}

\footnotetext{
*Eric Stein Distinguished University Professor of Law and Sociology, emeritus University of Michigan. Address correspondence to rlempert@umich.edu. I would like to thank Evan Caminker, David Chambers and William Kidder for comments on earlier drafts of this paper and Sarah Zearfoss for the assistance she and her staff have provided.

${ }^{1}$ Richard H. Sander, Listening to the Debate, On reforming Law School Admissions Preferences, 88 Denver L. Rev. 889 (2011)

${ }^{2}$ Professor Sander persists in this claim despite numerous published criticisms of both the methods he used and the results he reported from his analysis of data on students entering law school in 1991, as reported in the Law School Admission Council's Bar Passage Study. (BPS). See e.g. See, e.g., Ian Ayres \& Richard Brooks, Response, Does Affirmative Action Reduce the Number of Black Lawyers?, 57 STAN.L. REV. 1807 (2005); David L. Chambers et al., The Real Impact of Eliminating Affirmative Action in American Law Schools: An Empirical Critique of Richard Sander's Study, 57 STAN. L. REV. 1855; Daniel E. Ho, Reply, Affirmative Action's Affirmative Actions: A Reply to Sander, 114 YALE L.J. 2011 (2005); Daniel E. Ho, Scholarship Comment, Why Affirmative Action Does Not Cause Black Students to Fail the Bar,114 YALE L.J. 1997 (2005); Richard O. Lempert, William C. Kidd. Timothy T. Clydesdale \& David C. Chambers, Affirmative Action in American Law Schools: A Critical Response to Richard Sander's “A Reply to Critics" (Feb. 2006), Univ. of Michigan Law School Olin Center Working Paper No.60, available at http://law.bepress.com/cgi/viewcontent.cgi?article=1061\&context=umichlwps; Jesse Rothstein \& Albert Yoon, Mismatch in Law School (2009), http://gsppi.berkeley.edu/faculty/jrothstein/workingpapers/rothstein_yoon_ may2009.pdf. Many of these critics analyze the same data Professor Sander did, often using better suited, more sophisticated methods and none replicates his results, with some reporting opposite findings. Insofar as I know there is nothing in print that replicates Professor Sander's results or supports his methodological approach to the data, although there is some unpublished work that Professor Sander cites as doing this in an Amicus Brief he has submitted to the Supreme Court in connection with its upcoming (as of the summer of 2012) affirmative action case, Fisher v. Texas.
} 
American bar takers was about $78 \%$ and where there had been an opportunity for repeat test taking a bar passage rate exceeding $90 \%$ is a lower bound. I document these claims below and explain how I came to examine them.

\section{Professor Sander's Claims}

In our study of the career outcomes of minority and white lawyers during the first 27 years of affirmative action admissions at the University of Michigan, David Chambers, Terry Adams and I reported that between about $95.1 \%$ and $98.5 \%$ of our affirmative action eligible minority respondents told us they had passed at least one bar. ${ }^{3}$ We acknowledged in discussing our checks for non-response bias that our estimates of post law school success might show an upward bias due to selective non-response but believed, and still believe, that any such bias would be small and would be unlikely to distort in any important way our comparisons of minority and white University of Michigan law graduates. ${ }^{4}$

Recently Professor Sanders in an article published in the Denver Law Review. ${ }^{5}$ has sharply questioned our estimate of Michigan's minority bar pass rate. He writes of a study he conducted:

The results suggested that UMLS blacks taking a bar exam for the first time had a $62 \%$ pass rate; those taking multiple bar exams had an eventual success rate of 76\%. In other words, UMLS black performance on the bar was, as we guessed, a little worse than the rate found in the BPS for similar schools. This finding is, in my view, devastating to Lempert's study and to his testimony in Grutter. It also suggests that UMLS fits the pattern I have discussed with UCLA and George Mason. Students at a less-elite neighbor of UMLS - Wayne State University School of Law-have average credentials similar to or a little lower than those of UMLS blacks, but entering students have an aggregate graduation and first-time bar passage rate (in Michigan) of about 73\% (again, the rate for students at Wayne State with "average" credentials is almost certainly much higher). Taking attrition at the University of Michigan into account, conservatively, the comparable figure for black Michigan students during the same period is $60 \%$. This simple comparison thus suggests that the mismatch effect sharply lowers the success rates of the

\footnotetext{
${ }^{3}$ Lempert, Richard O., David L. Chambers and Terry K. Adams, Michigan's Minority Graduates in Practice: The River Runs Through Law School, 25 Law \& Soc. Inquiry 395, 422 (2000) (Hereinafter "Michigan's Minority Graduates")

${ }^{4} I d$ at 407 . The interested reader can review our discussion of possible non-response bias and the ways we checked for it at pp. 403-407.

${ }^{5}$ Richard H. Sander, Listening to the Debate, On reforming Law School Admissions Preferences, 88 Denver L. Rev. $889(2011)$
} 
purported beneficiaries of affirmative action at UMLS. Rather than being an exception that confounds mismatch theory, the University of Michigan fits the pattern. ${ }^{6}$

This is not the first time Professor Sander has made this claim, but he describes the claim, his justification for it and his methods in more detail than I have seen in the past ${ }^{7}$, and it is the first time I have seen it highlighted in a scholarly publication. ${ }^{8}$ Hence it is time to respond. ${ }^{9}$ But first a bit of history.

Professor Sander's claim, as I first heard it, was that using data he obtained in litigation against the University that was released to him in his capacity as an expert witness, he had found that that during the period 2004-2006 the University of Michigan's black law students failed the bar the first time they took it at about 8 times the rate of the school's white graduates. When upon first hearing the claim I requested that he describe his methods and share his data, he refused to cooperate with respect to either matter, saying he did this on advice of the attorney who secured the data for him. ${ }^{10}$ I responded by suggesting to Prof. Sander that so long as the data had been acquired pursuant to an informal agreement that they were for litigation purposes and so long as he refused to disclose his data and methods, he had an ethical obligation not to disseminate his results outside the context of the litigation. Obviously he disagreed, and in several settings I encountered the

\footnotetext{
${ }^{6} I d$ at 943

7 "More detail" does not mean sufficient detail. Professor Sander has not sent me nor have I elsewhere seen any tables indicating the numbers on which his percentages are based or the jurisdictions he included ( my replication assumes they include all those for which, according to what I was told, the University of Michigan Law School furnished information to the lawyer he was working with), and he has never discussed the difficulties he must have confronted in assigning races to graduates, difficulties I mention below.

${ }^{8}$ Sander, supra note 3at $940-943$

${ }^{9}$ Prof. Sander makes his arguments in a response to comments on an article he wrote claiming an absence of classbased diversity in American law schools. I was a commentator on that article, and although I pointed to numbers of difficulties with his measures and empirical analyses and suggested the case for class-based affirmative action was not as strong as the case for race-based affirmative action I was not, or at least did not intend to be, an unfriendly commentator. This portion of Professor Sander's response to the numerous commentators on his piece is very much an aside given the issue he was invited to address and the issues I and others raised. Not only was I surprised by this portion of his response, but its timing as a response to critics delivered long after its originally promised date, meant that the Denver Law Review could not afford me an opportunity to respond in print. Originally, however, I did not want to respond; rather I wanted Professor Sander to realize that he was wrong in his analysis or at least that there were substantial questions about the validity of his results and to refrain from publishing questionable data. Hence I sent him the data that appear below and also pointed out to him, as I do in this article, why the results of the Law School Admissions Council Bar Passage Study made his findings highly implausible. Professor Sander seems not to have believed that his results might be mistaken, for he made no significant changes in his draft, but he drop a footnote saying that I hotly disputed his claims and directs readers to a web site he controls for further discussion.. I visited the web site on July 3, 2012 but could not find relevant commentary. Nevertheless, I am grateful that he at least mentioned that I thought his results mistaken. As for the information I sent him, I did not even get the courtesy of a reply.

${ }^{10}$ This attorney wrote me, shortly before the case was dismissed, that his refusal to authorize the sharing of information was a matter of litigation strategy. I assume the note was written at Professor Sander's request.
} 
estimate that he has now published in the Denver Law Review. Thus the figure appeared in a news story, indicating that someone had called a reporter's attention to the expert report that contained Sander's findings; it was also noted in a footnote to an article by one of Professor Sander's associates, and Professor Sander referenced these results in a debate between him and me at the NYU Law School. During that debate for the first time I learned that he had identified the race of UM's bar takers through the use of UM's first year student facebooks ${ }^{11}$, which meant I could attempt to replicate the results of his research.

\section{Reasons for Skepicism}

Before discussing the methods and results of my replication attempt let me point out why I regarded Professor Sander's results as far off the mark even before I attempted to replicate his work and why he should have regarded his results with the same skepticism. First, I was confident that if Michigan's black graduates were performing as poorly on the bar as Professor Sander claimed, people at Michigan would have heard about it. This is not just hypothetical. In the first few years of Michigan's affirmative action admissions program African American bar passage rates in Michigan, the one state for which we had data, were unsatisfactorily low. Although the number of African American graduates failing to pass the bar was small because cohort sizes were small, the Michigan faculty and the state bar heard about it. One result was that the state bar began the practice of having its model answers vetted by law professors, ${ }^{12}$ and another was that the law school imposed a credential floor strict enough to provide good assurance that all affirmative action admittees could handle the work they would encounter at Michigan and graduate and pass the bar. So the first thing I did when I heard Sander's number was to check with the Michigan's Dean of Admissions and others at the law school who might track or otherwise be made aware of such data. No one gave credence to Sander's estimate.

\footnotetext{
${ }^{11}$ The bar passage data furnished to the University does not include information on the race of test takers, which is why Professor Sander had to acquire photos of bar takers as students to assign them to races. To my knowledge Michigan does not keep records by race of how its students fare on the bar, although I know at one time they did track this information for its African American graduates taking the Michigan bar. As for the name of the photo source, long before there was a company called Facebook, the UM Law School photographed its incoming students before their first class and created a booklet of their faces with their names and undergraduate institutions. This is generally referred to as the facebook.

${ }^{12}$ I recall vetting an evidence question that anyone who understood the law of evidence would have gotten wrong had the graders followed the model answer. The model was based on a decision by a Michigan intermediate appellate court judge who did not understand the rule he was interpreting.
} 
If this kind of anecdotal evidence is unlikely to carry as much weight with people who don't know Michigan Law School as it does with me, another prima facie argument should impress more. In 1991 the Law School Admissions Council began a study which followed more than 27,000 entering law students through their three years of law school and the bar exam, including repeated attempts at passing the bar if earlier attempts failed. The Bar Passage Study (BPS) data reveal that $94 \%$ of African American students attending one of the 14 law schools classified as elite who take the bar exam pass it, about $80 \%$ doing so on their first try. ${ }^{13}$ The claim that the University of Michigan Law School's minority students do about 18 percentage points worse both initially and eventually than comparable African American students at other elite law schools is prima facie absurd and any data suggesting this is rightfully suspect.

Professor Sander attempts to avoid absurdity by using as an expected outcome figure not the $94 \%$ eventual pass rate that characterizes African American students attending elite law schools, but a lower figure that lumps together bar passage outcomes for black test takers in the two most selective law school tiers. Since African American bar takers in the tier 2 schools ${ }^{14}$ do noticeably worse than African American students in the elite tier schools, lumping yields estimated bar passage figures that while still higher than Professor Sander's estimates for Michigan's African American law graduates are closer to the numbers he presents and the results he thinks we should expect. Professor Sander's justification for combining the rates of two tiers is that we can't be certain that Michigan falls in the Bar Passage Study's tier one rather than its tier two. I would be surprised if Michigan were not in the BPS top tier, but Professor Sander is correct in saying that that one cannot be certain of this. BPS tier construction although dominated by selectivity measures took account of other factors as well, and it is possible that a combination of non-selectivity factors meant that Michigan was placed in the BPS second tier.

It doesn't matter. Even if Michigan were in the BPS's second tier expectations about the bar performance of Michigan's black students should be based on the tier 1 statistics. Tier 1 contains 14 of the nation's most selective law

\footnotetext{
${ }^{13}$ Linda Wightman, LSAC National Bar Passage Study, LSAC Research Report Series (1998) Tables 11 and 7. Visited at http://www.unc.edu/edp/pdf/NLBPS.pdf July 3, 2012. The eventual pass rates for all affirmative action eligible minorities is of similar magnitude with the overall mean for this group being almost identical to the African American student mean. If one deflates the eventual bar passage rate by those minorities who matriculate but don't graduate the rate is about $89 \%$ of those who start at tier one law schools. Some portion of the missing $5 \%$ will have dropped out not for academic reasons but for financial reasons, family reasons, illness or a realization that law school is not for them.

${ }^{14}$ Sander calls the top two tiers in terms of selectivity 4 and 5. Following Weitzman I label them 1 and 2.
} 
schools. If these are not the study's 14 highest ranked or most selective law schools, they are surely 14 of the top 17 or 18 . Whether Michigan is in this group or not it remains true that when it comes to law school rankings and student selectivity Michigan is almost universally regarded as one of the nation's top ten law schools. It attracts students, black and white, Asian and Hispanic, commensurate with its reputation. Thus not only can Michigan's students, on the basis of their entrance credentials and the quality of a Michigan education, be expected to perform as well on the bar as the graduates of a typical tier 1 school, they can be expected, if anything to perform better than the graduates of a number of schools in that tier. ${ }^{15}$

\section{$\underline{\text { An Attempt at Replication }}$}

This latter point is so powerful that further analysis seems barely necessary. Nevertheless once I learned from his NYU comments how Professor Sander had conducted his research, I attempted to replicate it. I secured facebooks for the relevant years and the bar passage data that the law school had provided the attorney from whom Sander secured his data. The data included bar passage results for the years 2004, 2005, and 2006 from the states of California, Connecticut, Illinois, Kansas, Maine, Michigan, Missouri, New Jersey, New York, and Pennsylvania. Although University of Michigan graduates take the bar in many different states, these states together appear to account for the overwhelming majority, probably in excess of 90\%, of the Law School's first time bar test takers.

There are a variety of problems with the available data, which means there will inevitably be error in any estimates. One problem is that not every student's photo is included in the facebook. A second is that some pictures are ambiguous with respect to a student's race. A third is that if one is seeking to map students listed in bar results onto facebook pictures, unless one first recopies the names of the students listed in the bar results onto a separate list, in coding race one will know the student's bar result, which could influence how race is coded. A fourth is that some students who took the bar in more than one state are listed as first time takers in each state in which they took the bar because the state had no record of or chose not to note prior tests taken in other states. Fifth it is almost impossible to spot Native Americans or distinguish them from whites in facebook pictures, and Hispanics often also look white. Moreover, the quality of the facebook photos are

\footnotetext{
${ }^{15}$ I pointed this lumping error out to Professor Sander in a message sent before his article appeared. He never responded to my message and his published discussion ignores the point completely. Ironically, Michigan's standing and the likely performance of its graduates relative to the schools in tier 1 should be higher if Michigan is not in tier 1 than if it is, since Michigan would have been displaced in tier 1 by a less selective school.
} 
such that it is sometimes easy to confuse the photos of black students with those of Hispanics or darker complected white students or with students whose heritage is the Indian sub-continent. Finally, there are too few minority students to control for the state in which the bar is taken, even though bar passage rates are higher in some states than in others. In addition, although it does not affect coding decisions, there are no data on bar preparation, a variable one would want to control in assessing what bar passage or failure implies about a student's learning in law school. ${ }^{16}$

Professor Sander reports that he had two students coding student's race. I do not know what the students knew about their assigned project, but unless Professor Sander purposely recruited students who knew nothing about his work and views, they most likely knew the hypothesis Sander was seeking to prove. Still when it comes to appearances, his study does better than mine on this score. Had I been doing this study with publication in mind, I would certainly have used two coders as he did to check for intercoder reliability, ${ }^{17}$ and they would have been blind to the reason I was coding the race of facebook students. However, several years ago when I did the research whose results are reported below I was seeking to replicate Professor Sander's work not with a goal of publication, but simply to check on whether there could possibly be anything to Sander's claims. ${ }^{18}$

As indicated, I knew first time bar exam results when I coded ethnicity, although I took pains not to let that influence my coding. ${ }^{19}$ Those who want to be

\footnotetext{
${ }^{16}$ Bar prep information seems especially important in interpreting differences in first time bar pass results. Given the cost of many bar review courses, graduates who are less well off financially and those who do not take jobs with firms that will pay their bar review expenses and give them time off to study may decide to take the test once without any special preparation in the hope that they can pass it without spending an additional several thousand dollars and taking time away from the job. Bar preparation differences might in part explain why differences between minorities and whites in first time bar passage are so much greater than differences in eventual bar passage.

${ }^{17}$ Professor Sander tells us that his student coders were in substantial agreement but does not indicate any formal reliability checks, nor does he say whether they knew the reason they were being employed or tell us what proportion of the Facebook pictures were independently coded and what proportion were dual coded for the purpose of checking reliability.

${ }^{18}$ I would not be publishing these data had Sander not highlighted his results in print and come close to accusing me of perjury in doing so. See Sander supra note 941 where he converts my testimony that our study revealed that "almost all" Michigan's minority students passed the bar to testimony that Michigan's bar passage rate was "very close to 100\%" and that Michigan's African American students "essentially never failed." His former characterization may strike some as a fair encapsulization of the words I used in reporting our finding that, depending on the decade, between about 95 and 98 percent of our minority respondents reported having passed a bar exam. His "essentially never fail" is far off the mark because I was reporting eventual pass rates and some who pass the bar eventually fail it at least once before passing.

${ }^{19}$ I assume the same was true of Professor Sander's students. The reason bar exam results were the starting point is that to go from a facebook photo to the bar exam passage information meant that one might have to look through the results from all the states with available records, and even then one might find that there was no record of the student taking the bar in any of the reporting jurisdictions. Beginning with bar exam results, one simply had to go to
} 
suspicious will be suspicious, but I do not believe my coding was biased by any hopes or expectations. There are several reasons for this, beginning with an advantage I had over Professor Sander; namely I checked my judgments with people at Michigan who had known the students. Specifically, if I believed a facebook picture left doubt as to a student's racial/ethnic classification, I sought, as described below, an authoritative resolution from people who did not know whether the students inquired about had passed the bar. The same is true of students whose race/ethnicity I was able to identify although their pictures were not in a facebook. Moreover, coding occurred the first time a name was encountered. At this point I did not know that many of those I coded as "failing" would pass the bar on a subsequent examination. Finally, as will be seen, my findings indicate that few of Michigan's white graduates failed to pass a bar. This is additional evidence that I did not intentionally or subconsciously code minorities who failed the bar as white to make minority pass rates look better absolutely or relative to whites.

Professor Sander's figures apply only to Michigan's African American law graduates. I do not know whether he looked separately at students of other ethnic backgrounds, but I thought doing so might be instructive. Asians were coded both by features and by last or given names. Almost always these were congruent or checking, as described below, indicated congruence. I similarly coded Latinos by last or given and last name, except in the case of some students who looked Anglo and whose ethnicity I later checked.

Of the approximately first time test takers in the bar passage data provided me, there were about 250 who either could not be found in the facebooks for the most relevant classes or whose photos made their ethnic identity ambiguous. I listed these on a spreadsheet and asked the school's admissions director to identify the ethnicity of any of these students whom she or her staff recalled. In this way I was able to reduce the missing and ambiguous cases by somewhere between half and two-thirds, giving me a more complete sample than the sample Sander had available for analysis. ${ }^{20}$ Missing cases whom the admissions staff did not recall could not be coded unless they had either Asian or Latino last names (I did not try to distinguish white or black names) and ambiguous cases were resolved so as to favor the most likely ethnic group, which in almost every case meant that possibly

\footnotetext{
a name in the facebook and code the student's apparent ethnicity. Were I doing this study again but still on my own, or if I had done it originally with publication in mind, I would have a listed the names of all students whose bar results were reported without noting what the results were. Then I would have coded race/ethnicity from this list.

${ }^{20}$ As might be expected given staff turnover and the frailty of human memory, the admissions office was least able to help with the earliest cohort, those taking the bar for the first time in 2004.
} 
ambiguous passers were coded as white and possibly ambiguous failures were coded as black.

I don't know precisely how Professor Sander conducted his study since he has provided no details on his methods beyond saying that he had had two graduate students code facebook pictures, but I expect my results are at least as reliable as his and most likely more so because I enlisted the aid of law school personnel in identifying with certainty many missing and ambiguous cases. Hence my results call Professor Sander's claims into question not only because they fail to replicate his findings but also because where our results differ the findings I present are the more likely to be true. This is not just because of the advantages I enjoyed in reducing missing data and identifying those whose facebook portraits were ambiguous with respect to race, but also because my results are far closer than Professor Sander's to what the Bar Passage Study found to be true of the nation's most selective law schools.

There is one surprising result in the data which merits specific mention and suggests a potential difficulty of the methods used by Professor Sander. Among those who took the bar in 2004 and 2005 I could only identify 6 in each year who were Latino (A number of others - all but one passers - had Latino sounding last names but according to the Admissions' Office all but one of those who could be identified were white.) Among the 2006 test takers, however, 27 appeared to be Latino. The 2004 and 2005 numbers may miss a few Latinos who took the bar in the ten study jurisdictions but they are most likely close to accurate given the number of Latinos graduating from Michigan during those years, the absence of information on bar takers in Texas, Florida or the Southwest, and postponements in taking the bar for further education or clerkships. The 2006 Latino number almost certainly includes a number of students who despite their names should not have been included. But since every one of these students passed the bar on first try, mistaken inclusions do nothing to inflate the true 2006 Latino pass rate.

\section{What the Data Show}

The relevant data are presented in Table One and in the three parts of Table Two. Looking at the overall first time bar pass rates across the three years studied, we see that $95.9 \%$ of UM's white graduates passed the bar on their first try compared to $78.3 \%$ of the school's African American graduates. One way, but a possibly misleading way, to characterize this difference is to say that the percentage of Black test takers failing on their first attempt is a little over 5 times the white failure rate. (Sander's estimate was 8 times.) 


\section{Table One}

Bar Passage Rate by Ethnicity (2004-2006)

\begin{tabular}{|c|c|c|c|c|c|c|}
\hline $\begin{array}{l}\text { Ethnicity } \\
\text { (\# all/\#'04-05) }\end{array}$ & $\begin{array}{l}\% \text { First } \\
\text { Time } \\
\text { Pass }\end{array}$ & $\begin{array}{l}\% \text { First } \\
\text { Time } \\
\text { Fail }\end{array}$ & $\begin{array}{l}\text { \% Ever } \\
\text { Pass }\end{array}$ & $\begin{array}{l}\% \text { No } \\
\text { Pass } \\
\text { Record }\end{array}$ & $\begin{array}{l}\% \text { Ever } \\
\text { Pass } \\
2004-05\end{array}$ & $\begin{array}{l}\% \text { No } \\
\text { Pass } \\
\text { Record } \\
\text { 2004-05 }\end{array}$ \\
\hline Whites $(753 / 483)$ & $95.9 \%$ & $4.1 \%$ & $98.3 \%$ & $1.7 \%$ & $99 \%$ & $1 \%$ \\
\hline Asians $(89 / 60)$ & $83.1 \%$ & $16.9 \%$ & $86.5 \%$ & $13.5 \%$ & $95 \%$ & $5 \%$ \\
\hline Blacks (46/33) & $78.3 \%$ & $21.7 \%$ & $84.8 \%$ & $15.2 \%$ & $90.9 \%$ & $9.1 \%$ \\
\hline Latinos (39/12) & $97.4 \%$ & $2.6 \%$ & $100 \%$ & -- & $100 \%$ & -- \\
\hline
\end{tabular}

A failure rate for African Americans that is 5 times as great as it is for Whites is potentially a matter of serious concern, although if the white failure rate is low, focusing on the failure ratio may make the black bar passage discrepancy seem bleaker than it is. Thus, it is also correct to say of the data below that the black first time bar passage rate is $82 \%$ of the white rate. Regardless of what base one uses and how small or large the discrepancy is made to appear, the concern should be the same. And regardless of what rate one uses, there is a good deal about this difference that is misleading. First, only a small number of African American students attend and graduate Michigan, so the percentage of passers can change dramatically based on the results from a few students. Among 2004 test takers for example, the ratio of the percent of African American first time failures to the percent of white failures is a bit under 3, and the African American first time bar exam success rate is about $91 \%$ of the white success rate. And if one more African American graduate who took the bar first in 2005 had later passed, Michigan's eventual African American bar passage rate would have exceeded the eventual bar passage rates of its white and Asian test takers. 
Two aspects of the data are more important than the ratio of failing or passing black to failing or passing white first time takers. The first is the proportion of African Americans who ever passed the bar, since one need not pass the bar the first time one takes it to become a lawyer, and many law school graduates pass the bar only on a second or later attempt. Over the three years for which we have data, $84.8 \%$ of African American students and $98.3 \%$ of white students who were first time takers in the sample were eventual bar passers, but this estimate of overall African American bar passage is low for three reasons. One is that it is easy to miss a students who failed the bar on a first attempt in one state and then passed it in another. Second, some students who failed the bar the first time they took it in one state may already have been members of another state's bar or may have taken and passed the bar in a state that does not report to the law school. The third, and most important reason, is that some students may have gone on to take and pass the bar in a year after the last year for which there are data. Indeed, in no case where the bar was failed in 2006 was there evidence in the data of later bar passage, but that is because only the very small number of graduates who took and failed a bar in the winter of 2006 would have had even one chance to retake it. So a better estimate of the proportion of Michigan's African American students who pass the bar is based on those who took the bar for the first time in 2004 or 2005 . If these students failed, they would have been able to retake the test from 2 to 5 times depending on when they first failed. Looking just at those black students who took the bar in 2004 or 2005 , we see that $90.9 \%$ of them had passed at least one bar by the end of 2006. Numerically this means that of 33 black Michigan graduates who took the bar for the first time in the ten study states during 2004 and 2005, by 2006 at most 3 had not passed a bar. Three is, however, likely to overestimate the number of these first time takers who never passed a bar since some may have passed a bar in non-reporting jurisdictions or after 2006. (A number of UM graduates, both white and minority, pass the bar only after a $3^{\text {rd }}$ or later attempt.) Thus the minority bar passage rate of about 95 98\% minority bar passers which David Chambers, Terry Adams and I report in our study may, as we acknowledged, err slightly on the high side, but contrary to Professor Sander's claim, it is consistent with rather than refuted by the more recent bar data, especially since a number of states had toughened their bar passage requirements by 2004. Hence, the figure we report remains a good estimate of the proportion of Michigan's African American and other minority graduates who become members of at least one bar, a conclusion confirmed by the Bar Passage Study's finding that about $94 \%$ of African American bar takers in their sample of elite law schools passed at least one bar. 
The second important point that appears from the data, contradicts the most important lesson that Professor Sander would have us draw from his analysis. Rather than supporting the mismatch hypothesis, mismatch associated with

affirmative action appears to have little if anything to do with bar passage rates. Latinos who like African Americans are an affirmative action eligible minority have bar passage rates comparable to or perhaps higher than the first time and overall bar passage rates of white students. Asians, who were not a minority eligible for race-based affirmative action, have, on the other hand, bar passage rates comparable to African Americans. Thus, over all three years UMs Asian graduates are only about 1.25 times more likely to pass the bar on their first attempt than its African American graduates, and among the Law School's graduates who took a state bar for the first time in 2004 or 2006 Asian and African American bar passage rates are virtually identical.

Table Two (A)

Table Two

Bar Passage Rates by Ethnicity and Cohort

Bar Passage Rate by Ethnicity - 2004

\begin{tabular}{|c|c|c|c|c|}
\hline Ethnicity (\#) & $\begin{array}{l}\text { \% First } \\
\text { Time } \\
\text { Pass }\end{array}$ & $\begin{array}{l}\text { \%First } \\
\text { Time } \\
\text { Fail }\end{array}$ & $\begin{array}{l}\text { \% Ever } \\
\text { Pass }\end{array}$ & $\begin{array}{l}\% \text { No } \\
\text { Pass } \\
\text { Record }\end{array}$ \\
\hline Whites (242) & $94.6 \%$ & $5.4 \%$ & $99 \%$ & $1 \%$ \\
\hline Asians (35) & $85.7 \%$ & $14.3 \%$ & $94.3 \%$ & $5.7 \%$ \\
\hline Blacks (19) & $84.2 \%$ & $15.8 \%$ & $89.5 \%$ & $10.5 \%$ \\
\hline Latinos (6) & $83.3 \%$ & $16.7 \%$ & $100 \%$ & -- \\
\hline
\end{tabular}


Table Two (B)

Bar Passage Rate by Ethnicity - 2005

\begin{tabular}{|c|c|c|c|c|}
\hline Ethnicity (\#) & $\begin{array}{l}\text { \% First } \\
\text { Time } \\
\text { Pass }\end{array}$ & $\begin{array}{l}\text { \%First } \\
\text { Time } \\
\text { Fail }\end{array}$ & $\begin{array}{l}\% \text { Ever } \\
\text { Pass }\end{array}$ & $\begin{array}{l}\% \text { No } \\
\text { Pass } \\
\text { Record }\end{array}$ \\
\hline Whites (241) & $95.9 \%$ & $4.1 \%$ & $98.8 \%$ & $1.2 \%$ \\
\hline Asians (25) & $92 \%$ & $8 \%$ & $96 \%$ & $4 \%$ \\
\hline Blacks (14) & $78.6 \%$ & $21.4 \%$ & $92.9 \%$ & $7.1 \%$ \\
\hline Latinos (6) & $100 \%$ & - & $100 \%$ & -- \\
\hline
\end{tabular}

Table Two (C)

Bar Passage Rate by Ethnicity - 2006

\begin{tabular}{|c|c|c|c|c|}
\hline Ethnicity (\#) & $\begin{array}{l}\text { \% First } \\
\text { Time } \\
\text { Pass }\end{array}$ & $\begin{array}{l}\text { \%First } \\
\text { Time } \\
\text { Fail }\end{array}$ & $\begin{array}{l}\% \text { Ever } \\
\text { Pass }\end{array}$ & $\begin{array}{l}\% \text { No } \\
\text { Pass } \\
\text { Record }\end{array}$ \\
\hline Whites (270) & $96.7 \%$ & $3.3 \%$ & $96.7 \%$ & $3.3 \%$ \\
\hline Asians (29) & $69 \%$ & $31 \%$ & $69 \%$ & $31 \%$ \\
\hline Blacks (13) & $69.2 \%$ & $30.8 \%$ & $69.2 \%$ & $30.8 \%$ \\
\hline Latinos (27) & $100 \%$ & - & $100 \%$ & -- \\
\hline
\end{tabular}

The similarity between the bar success of Whites and Latinos on the one hand and Asians and African Americans on the other is fascinating and well worth 
exploring. An in depth study might help us tease out factors that generally make for difficulties on the bar. Perhaps there is differential vulnerability to stereotype threat since most Latino law graduates are by appearance indistinguishable from the school's white graduates, while Asians and African Americans can be identified by their different appearance. Perhaps it has something to do with bar preparation or the states in which bars are taken. Perhaps the results are mere coincidence, enabled by the school's small numbers of minority test takers. It would be nice to know, but whatever the reason these data do not suggest that socalled academic mismatch, to the degree it exists at Michigan, hurts minorities on the bar exam.

\section{Comparison With Wayne}

In the paragraph extracted above Professor Sander sought to bolster his claim of a detrimental mismatch effect by contrasting the bar success of Michigan's African American law graduates with those of Wayne State's graduates. He wrote:

Students at a less-elite neighbor of UMLS - Wayne State University School of Law-have average credentials similar to or a little lower than those of UMLS blacks, but entering students have an aggregate graduation and first-time bar passage rate (in Michigan) of about $73 \%$ (again, the rate for students at Wayne State with "average" credentials is almost certainly much higher). Taking attrition at the University of Michigan into account, conservatively, the comparable figure for black Michigan students during the same period is $60 \% .^{21}$

I had a hard time figuring out how this comparison was derived, and when I wrote to Professor Sander seeking more information rather than explain in detail he directed me to the footnote to this statement which reads:

See, e.g., AMER. BAR ASS'N, ABA-LSAC OFFICIAL GUIDE TO ABA-APPROVED LAW SCHOOLS (2002-05 editions). As with the analysis of Howard, supra, I analyzed four years of attrition and bar passage statistics for Wayne State. Because of the small sample size in the disclosed data, the Michigan estimate applies to blacks taking the bar in all the states disclosed by UMLS.

What Professor Sander appears to have done is to look in the ABA-LSAC Official Guide To ABA-Approved Law Schools (Official Guide) which reports the first time bar passage rate for each law school in the jurisdiction where the

\footnotetext{
${ }^{21}$ Supra note 4
} 
plurality of the school's graduates take the bar exam. For Wayne State this jurisdiction is Michigan. Professor Sander apparently then took Wayne's first time passing rates and averaged them across the four years he was studying and found the average first time passing rate was $73 \%$. Although he does not highlight it, the Wayne State figure is for all of Wayne's graduates and not just its African American graduates, nor is the latter information available from the Official Guide. Except for one year the Official Guide does not include first time Michigan pass rates for University of Michigan Law School graduates since New York and Illinois are the jurisdictions in which most Michigan's graduates take the $\operatorname{bar}^{22}$, nor does it provide first time Michigan Bar Pass rates for Michigan's African American graduates. So, if I understand correctly, Professor Sander assumes that Michigan's black graduates pass the Michigan Bar on their first try at the same rate they pass the bar in all jurisdictions on their first try according to his calculations. ${ }^{23}$ He further assumes, without citing any evidence, that Michigan's African American admittees have credentials that are on average like those of Wayne State's entire entering class. In addition, he assumes that these entering credentials correlate so highly with what is learned in law school that if Michigan's African American students had gone to and graduated from Wayne, they would pass the Michigan bar at the same rate as Wayne's graduates do. Finally, Professor Sander deflates his estimate of Michigan's first time national bar pass rate by an additional $2 \%$ to account for attrition. His only basis for doing this, however, is the information on attrition by school presented in the Official Guide, which is not broken down by race. These data shows Michigan to have very little attrition and indicate that among those who leave Michigan before graduation on average fewer

\footnotetext{
${ }^{22}$ The Official Guide only provides Wayne data on Michigan Bar Takers for the period Professor Sander is investigating. Over the same time frame it provides figures on the two jurisdictions that attract the most Michigan law school bar takers for the same period. Illinois is always the number 2 school except in 2005 where Michigan is second. That report indicates that $96 \%$ of Michigan's state bar test takers passed the bar on their first attempt. Given the number of Michigan students sitting for the bar, this means that only three of the school's test takers failed. In the same year 33 students or 17\% of Wayne's test takers failed the bar on their first try. The Official report provides no data on the race of the students who failed.

${ }^{23}$ The need for this assumption is questionable since Professor Sander had data on who passed the Michigan bar for at least some of the years of interest, and his research should have told him which of these students were African Americans. He says that the small number of Michigan's African American graduates taking the bar in Michigan led him to substitute his estimate of the national first time Michigan African American bar passage rate for the Michigan specific rate he might have constructed. It is hard to see the justification for this, especially since Michigan's bar exam may have been easier to pass in the years in question than bar examinations in other jurisdictions, like New York and California, where more of Michigan's graduates take the bar. Whether it was is hard to say because bar pass rates like California's that are considerably lower than in Michigan's or those that are higher like Illinois's say little about the ease of bar passage unless one can control for the skill and training of those taking bar exams in different states. Thus the best evidence for comparing the success of Wayne's graduates to those of Michigan's minority graduates would be whatever data exist on how Michigan's minority graduates do on the Michigan bar. Is it perhaps overly cynical to wonder whether in Professor Sander's racially coded data the bar passage rate of Michigan's African American bar takers who took the bar in Michigan exceeds the Wayne State rate he uses as a benchmark? I think not.
} 
than 1.5 a year depart for academic reasons. It is not clear whether Professor Sander's Wayne bar passage data are similarly deflated, but Wayne has substantially more attrition than Michigan for both academic and non-academic reasons. $^{24}$

The data presented in the tables above, which show that Michigan's African American graduates have a first time bar pass rate of $78.3 \%$, undermines Professor Sander's claims about the Wayne State comparison just as it does his overall estimate of Michigan's African American bar passage rate. Indeed, if one accepts the assumptions that Professor Sander uses to justify substituting Michigan's national first time African American bar passage rate for a Michigan only rate and for expecting Michigan's black graduates would pass the bar on first try at the same rate as Wayne's graduates if they went to Wayne, then the data suggest that far from being victims of mismatch, Michigan's African American law students benefit from attending one of the nation's most selective law schools rather than one where their admissions credentials would be closer to those of their white colleagues.

\section{Assumptions About Data}

Empirical analysis requires data, but it is easy to be misled when assumptions, however plausible, substitute for deeper knowledge of what data mean. This danger is particularly great when assumptions conduce to conclusions one wishes to reach. In seeking to assess Professor Sander's claims regarding the Michigan-Wayne state comparison I inadvertently stumbled upon a nice example of how easy and plausible assumptions can mislead. Because I too quickly read his footnote when I originally looked at his analysis I did not realize that Professor

\footnotetext{
${ }^{24}$ Over the nine years period, 2002 through 2010, the Official Guide reports that 11 Michigan students left law school for academic reasons, while 91 left for other reasons. For Wayne over the same 9 years there were 59 students who left for academic reasons and 249 for other reasons. In both schools, but Wayne more than Michigan, a portion of the non-academic leavers will be among the school's highest performing first year students who transfer to what they regard as more prestigious institutions. (My Michigan figures differ from what will be found in the Guides because I count 13 students who are listed in the 2003 Official Guide as having left for academic reasons as having left for other reasons. All 13 students are reported as having left in their first or second years and none in their third year. Yet all 11 Michigan students who in other years were reported as having left for academic reasons left in their third year and none in their first two years. Similarly, only 3 of 78 students who left Michigan for other reasons in the other eight years for which I have data left in their third year. This is consistent with the zero third year leavers reported in the 2003 data. Also during the year before and the two years after the 2003 report no Michigan students are reported as having left for academic reasons so the figure 13 is quite out of line. Finally in none of the other 8 years does the Guide show fewer than 6 Michigan students leaving for other than academic reasons, and the average number of leavers is close to ten. The 2003 Guide reports zero Michigan students leaving for non-academic reasons. These data make it clear that the students who were listed as leaving for academic reasons in 2003 should be in the non-academic reasons column. An accidental transposition of the data has occurred, and the numbers I give correct for this.)
} 
Sander's 60\% first time African American bar passage estimate was simply the national estimate he had already given deflated by a few percentage points to account for posited attrition. Rather I thought his estimated attrition rates were much higher and I assumed he had gotten this information from the Official Guide which Professor Sander cited as the source of his information. ${ }^{25}$ Looking at the guide I could see only one way in which he might have derived his figures. During the years in question the Guide listed the number of African American students admitted in each cohort and the number of African American students receiving J.D.s in the same year. Hence it is plausible to assume that by subtracting the number of students graduating in a given year from the number of students entering 3 years earlier, one could identify those students who failed to make it through law school. At first glance an approach like this seemed to support Professor Sander's claims, since in the first year of his series (the 2002 Guide) 35 African American students were reported as having entered Michigan, and in 2005, their expected year of graduation, only 20 were listed as having received J.D. degrees. ${ }^{26}$ This is a dramatic fall off, which would suggest that Michigan was admitting many African American students who could not make it through to the completion of their degree. It could be seen as providing substantial support for the mismatch hypothesis. Hence to see whether academic mismatch might have played a role here, I asked the Law School's admission's officer if she could help me determine what had happened to those students who appeared to have entered Michigan and not graduated. What I found is an object lesson in the dangers of making assumptions about what data reveal when one does not know how the data were generated and/or what actually was happening; especially when the apparent implications of data are inconsistent with other things one knows. ${ }^{27}$

Here is what an investigation into the specifics of this drop off revealed. Four of the missing blacks students were not listed as having received J.D.'s because they had not listed their race at graduation and had moved into the Guide's "race unknown" category. At least one of the delayed recipients was a dual degree student, and 5 others graduated in 2006 for reasons I could not determine. This left 5 African American students unaccounted for. One of them had transferred to Harvard, hardly evidence for suffering from mismatch. ${ }^{28}$ A second at the time of

\footnotetext{
${ }^{25}$ If I now understand correctly this was his source only for the Wayne State Michigan bar passage data and for the degree of attrition among law students entering Michigan.

${ }^{26}$ The data in the Guide, I later learned, is two years out of date, so we are really talking about black students who entered in 2000.

${ }^{27}$ I knew that a black attrition rate this high would have attracted substantial attention within and outside of the law school, yet neither I nor anyone I knew at Michigan knew anything about this.

${ }^{28} \mathrm{I}$ do not know the entering credentials of this student or of any others whose situations I am describing. It may be that one or more of them would have gained admission to Michigan without benefit of affirmative action.
} 
leaving had an average that placed him/her in the top half of the class. Two of the remaining students were in the lower portion of the class but had grade point averages of 2.5 or above and no prospect of academic difficulty. The one remaining student, although maintaining a passing grade point average, was close enough to the passing border that it is not unreasonable to suppose that this student left for academic reasons. In short it appears that of those students who did not graduate "on time" at most one among 35 African American admittees was having substantial difficulty in doing work at the passing level. Two others were in the lower portion of their class but so were a number of white students. ${ }^{29}$ The cohort described in the 2002 Official Guide was, I might add, unusual. In other entering cohorts I looked at, the number of black students receiving J.D.s was almost the same as, and in some cases the same or greater than, the number of black students who had entered law school three years before.

\section{$\underline{\text { Conclusion }}$}

To sum up, Professor Sander's results suggesting that more than one-third of Michigan's African American law students fail the bar the first time they take it and that almost one-quarter of these students never pass a bar do not hold up to replication using similar methods with a substantially more complete sample and the authoritative, outcome blind categorization of ambiguous and missing cases. Looking just at graduates in the 2004 and 2005 cohorts who have had at least one occasion to pass the bar if they did not pass on their first try, we see that about $91 \%$ of Michigan's black graduates passed at least one bar. Moreover, this number is a lower bound, since some graduates in this cohort may have retaken and passed the bar in a state that did not report its bar outcomes to the law school or have retaken and passed the bar after the period for which data were available. Hence the close to $94 \%$ pass rate which the BPS found when it examined the bar exam success of African American law students at 14 of the nation's most selective law schools is a reasonable estimate of the rate at which Michigan's black law students who take one or more bar exams pass at least one. Since very few Michigan Law students drop out for any reason the proportion of African American law students entering

\footnotetext{
${ }^{29}$ Whatever admissions standard one applies some people must be near the bottom. If there were only white students in a class, there would be an all white bottom 10\%. Professor Sander has on numbers of occasions pointed to the fact that Michigan's African American students are quite disproportionately represented in the bottom 10\% of their class ( See e.g. Sander spra note 3 at 942) and suggests that this reflects a failure to learn caused by mismatch and evidenced in an inability to pass a bar. No one, however, has suggested that white students who graduate in the bottom $10 \%$ of the class with grade point averages below many of their African American colleagues are not capable of passing the bar and becoming successful practicing lawyers. So long as the passing level is set to capture those of adequate competence, the fact that those with lower entrance credentials are likely to do worse gradewise in law school than those with higher entrance credentials has few implications for their ability to graduate, to pass the bar and, as Chambers, Adams and I have shown, to have successful legal careers.
} 
Michigan who graduate and pass the bar will be close to this figure, and to the extent there is attrition most is unlikely to be due to the kind of academic difficulty that Professor Sander seeks to associate with mismatch. Thus the figures on bar passage which David Chambers, Terry Adams and I present in our article on the career success of Michigan's minority students appears to be very close to what we would have found had all alumni in our sample responded. ${ }^{30}$

Not only is Professor Sander's mismatch theory unsupported by the Michigan bar passage data, but these data call his theory into question. If one accepts Professor Sander's claim that 73\% of Michigan's black law students would have passed the bar on their first attempt had they gone to Wayne State, then the $78 \%$ first time pass rate we see in the data suggests that Michigan's black students benefited from preferring a more selective law school to one where they would have been better matched. I don't want to make too much of this, however, for I don't accept the assumptions Professor Sander makes to allow this comparison and the difference may not be statistically significant.. More to the point is what the data I have presented reveal. Michigan's Latino students, many of whom benefited from affirmative action, have first time and overall bar pass rates identical to those of its white graduates. We should not see this if mismatch is a problem. In addition, in two of the three cohorts we have data for, Michigan's African American graduates have first time bar pass rates virtually identical to those of its Asian graduates and ever pass rates above $90 \%$ and within $5 \%$ of the Asian bar pass rates. Since many African Americans benefitted from affirmative action admissions and Asian applicants did not, we should not see such similar bar success rates if mismatch meant that blacks were at a substantial educational disadvantage.

I sent Professor Sander the results of my analysis before he published his findings in the hope he would refrain from publishing questionable results. Since he did not refrain, I have felt compelled to set the record straight.

\footnotetext{
${ }^{30}$ Note that the bar passage figures in Michigan's Minority Graduates, supra note 3 are for minorities and not just African Americans, with most of the other minority alumni being of Hispanic heritage. The data presented above suggest that Michigan's Hispanic alumni do even better on the bar exam than its black alumni. This makes a pass rate somewhat in excess of what the BPS found for black law students at elite law schools not just plausible but likely. If there is any bias in the data, most of it may be due to the fact that those who did not become lawyers because they had no need for legal certification once they started on their careers were probably somewhat less likely to respond than those who had legal careers. Thus the school's overall bar passage rate might be a bit lower than we found simply because not every Michigan graduate takes the bar. Based on what I have seen anecdotally (e.g. who goes into a Ph.D. program or business immediately upon graduation) this bias would probably inflate the white bar passage rates more than the reported minority results, further diminishing differences between the bar exam success of Michigan's white and minority graduates..
} 